File name IASL2015Lukenbill 
Living in the Digital Age:

Youth, Prosocial Behavior, and the Broadway Musical 


\title{
Living in the Digital Age: \\ Youth, Prosocial Behavior, and the Broadway Musical
}

\author{
W. Bermard (Bill) Lukenbill \\ Professor Emeritus \\ School of Information, \\ University of Texas at Austin \\ United States of America \\ lukenbill@mail.com
}




\section{Abstract \\ Living in the Digital Age:}

Youth, Prosocial Behavior, and the Broadway Musical

Discusses the American Broadway musical as performed in American high schools and concentrates on prosocial behaviors that are featured in these musicals and available in digital formats. The paper describes prosocial behaviors as "[...] a broad range of actions intended to benefit one or more people other than oneself - behaviors such as helping, comforting, sharing and cooperation." Prosocial behavior can also be understood as "[...] a type of helping behavior [extended to others] that ultimately confers some benefits to the self." This paper expands on these descriptions to include the following: acceptance of self and others; honoring commitments; appreciation of diversity; deciding on a direction in life; recognizing oppression, prejudice, and stereotyping; appreciation of self-awareness; and comfort with self-expression (Cherry). This paper explores how musicals can be used in the classroom to encourage prosocial behaviors among youth. Using available digital media such as audio recordings and DVDs,

Musical theatre; prosocial behaviors; Broadway musicals; Youth 


\section{Living in the Digital Age:}

\section{Youth, Prosocial Behavior, and the Broadway Musical}

\section{Introduction}

The Broadway musical holds a significant place in American and world cultures. According to Jones (2003), the American Broadway musical has played an important role in American life and social development. Specifically, he describes the ways musical theater has influenced and reflected American political life, culture, and social structures. Kirle (2005). similarly explored how Broadway musicals address various social tensions as they arise in American contemporary society.

Teacher-Librarians are very much a part of the wide-based digital age inhabited by the Broadway musical and today's youth. We offer opportunities to expand on and to influence positive behaviors in youth through the applications of digital formats, including the Broadway musical. This paper discusses the American Broadway musical as performed in American high schools and concentrates on positive behavior models that are featured in these musicals.

Positive behavior is what psychologists and other social scientists call "prosocial behavior." Prosocial behavior as a concept was introduced in the 1970s, and it is defined as behaviors that are directed at helping others. These behaviors include empathy and standing up for the rights, feelings, and the general welfare of other people (Cherry).

There are many reasons why youth act in prosocial ways. This behavior is often encouraged by adults while in childhood and adolescence. Youth are directed to share, be kind, and to help. Helping one's family is promoted as positive behavior, and it often supports survival of self and the family unit. This can be expanded to helping the extended family, the clan, and the tribe. Psychologists explain that reciprocation is often expected within this helping structure (Cherry). Beyond the family and close relationships, examples of institutional prosocial behaviors include patriotism to one's country, devotions, and providing support for important institutions such as religious groups.

\section{A Brief History of the American Musical}

In modern times, the Broadway musical owes much of its development to Gilbert and Sullivan and other British musicals of the 19th century (Bradley, p.41-62). .Most musicals of the early 20th century favored musical voices and performers over story and social message. Show Boat, based on the novel by Edna Thurber and produced in 1927, introduced realism to the musical theater. The musical explored the lives of many people who performed and worked on the river boat, Cotton Blossom. It exposed racism, alcoholism, hard labor, tragic love, gambling, family breakups, and institutional state oppression (Bradley, p.63). A description of Show Boat reads as follows:

Here we come to a completely new genre - the musical play as distinguished from musical comedy. Now [...] the play was the thing, and everything else was subservient to that play. Now [...] came complete integration of song, humor and production numbers into a single and inextricable artistic entity (Lubbock, and Ewen). 
Some years later, Rogers and Hammerstein followed this landmark by also departing from prevailing patterns and giving more importance to words, plots, and characters as enhanced by lyrics and music. Characters and their life problems, together with their surrounding social environments, were essential elements in their musicals. They infused their musicals with idealistic and moral messages, along with an uplifting spirit of optimism. Their works helped drive musical theater in America towards a more realistic and social relevancy. This in turn paved the way for later writers such as Tim Rice, Lloyd Webber, and Steven Sondheim to emerge (Bradley, p.62).

\section{Musical Theater in American High Schools}

Music and drama are an integral part of American secondary public school curriculums. These programs include military and symphonic bands, orchestras, and choral groups, and span curricula and course offerings. Most states have developed instruction guides that outline specific expectations and outcomes for these courses. These programs exist in standard secondary schools as well as selective arts academies that flourish within many public schools. Collaboration among the various arts programs within each school is mandated in the production of a student-based Broadway musical theater.

\section{Method of Study}

For this study, I selected 10 musicals as suggested by a musical authority with extensive experience in musical productions, including young adult theater groups. Most of the musical theater selections were recognized as outstanding, awarding-winning performances given by high schools in the United States for 2007 and 2008.

Along with previously discussed prosocial behaviors, specific prosocial behaviors addressed here include acceptance of self and others; honoring commitments; appreciation of diversity; deciding on a direction in life; recognizing oppression, prejudice, and stereotyping; self-awareness; and self-expression.

To maintain consistency, annotations below that describe the basic plots of musicals are quoted directly from various sources. Sources are provided after each annotation along with prosocial behaviors. Although Billy Elliot was not performed in American high schools from 2007-2008, it was included because of its focus on prosocial behaviors. All of these productions are available in digital formats as noted in the descriptions.

- All Shook Up (Behaviors: love and caring). American jukebox musical with Elvis Presley music. The story is based on William Shakespeare's 1602 play Twelfth Night (Wikipedia). Productions: 2007, Bentonville High School, Bentonville, Arkansas; 2008, Valley Regional High School, Deep River, Connecticut.

- Billy Elliot (musical not identified as performed in high schools from 2007-2008). (Behaviors: self-expression, transformation, community, family, conflicts, values). The story of his personal struggle and fulfillment are balanced against a counter-story of family and community strife caused by the UK miners' strike (1984-1985) in County Durham, in North Eastern England (Wikipedia). "As Billy's hopes and dreams grow bigger and the strike escalates, the family and the community are both challenged to 
consider and fight for that which is truly most important" (Wikiprdia). No high school productions.

- Evita (Behaviors: society and community, self; truth and social reality). The life of Argentine political leader Eva Perón, the second wife of Argentine president, Juan Perón. The story follows Evita's early life, rise to power, charity work, and eventual death (Wikipedia). "When her lover, Colonel Juan Perón, becomes elected president she reaches the height of her fame and at the end of her life questions whether or not she took the right path" (Broadway Musical Home). Production: 2008, Sanford School, Hockessin, Delaware.

- Fiddler on the Roof (Behaviors: family, community, traditions; racism, oppression). Set in Russia in 1905. "When Tevye's eldest daughter, Tzeitel, begs him to let her marry a poor tailor rather than the middle-aged butcher that he has already chosen for her, Tevye must choose between his own daughter's happiness and those beloved traditions that keep the outside world at bay. Meanwhile, there are other [...] dangerous forces which threaten to destroy the very life he is trying to preserve." (Broadway Musical Home). Productions: 2007, Oaks Christian High School, Westlake Village, California, and Clovis High School, Clovis, New Mexico; 2008, Topeka West High School, Topeka, Kansas.

- Into the Woods (Behaviors: opportunity, loyalty, uncertainly, selfishness). "The musical intertwines the plots of several Brothers Grimm and Charles Perrault fairy tales, exploring the consequences of the characters' wishes and quests" (Broadway Musical Home). Productions: 2007, Gresham High School, Gresham, Oregon; 2008, Mount Blue High School, Farmington, Maine.

- Jekyll and Hyde (Behaviors: being-oneself; self-awareness)."Dr. Jekyll unwittingly unleashes his dark side while trying to find a cure for his father's mental illness and begins committing murders as Dr. Hyde" (Broadway Musical Home). Productions: 2007, St. Francis High School, St. Francis, Minnesota; 2008, Mount de Sales Academy, Macon, Georgia.

- Les Misérables (Behaviors: helping others, life transformation, justice, the political state). "Set in early $19^{\text {th }}$ century, [the play tells] the story of Jean Valjean, a French peasant, and his quest for redemption after serving nineteen years in jail for having stolen a loaf of bread for his sister's starving child. Valjean decides to break his parole and start his life anew after a kindly bishop inspires him by a tremendous act of mercy, but he is relentlessly tracked down by a police inspector named Javert. Along the way, Valjean and a slew of characters are swept into a revolutionary period in France, where a group of young idealists make their last stand at a street barricade" (Wikipedia). "Political and personal stories become intertwined, and all are called to question their devotion to freedom, love, and justice" (Broadway Musical Home). Productions: 2007, Ponderosa High School, Ponderosa, Colorado; 2008, Grosse Point South High School, Grosse Pointe Farms, Michigan; Northridge High School, Layton, Utah; Bellingham Sehorme, Ferndale and Squalicum High Schools, Bellingham and Ferndale, Washington.

- Oklahoma! (Behaviors: accepting diversity, community, democracy). "Set in Oklahoma Territory outside the town of Claremore in 1906, it tells the story of cowboy Curly McLain 
and his romance with farm girl Laurey Williams" (Wikipedia). "Laurey is a headstrong farm girl and the woman with whom both cowboy Curly and farm hand Jud have fallen in love" (Broadway Musical Home). Performance: 2007 and 2008, Jenks High School, Jenks, Oklahoma.

- Phantom of the Opera (Behaviors: acceptance, redemption).The play [...] revolves around a beautiful soprano, Christine Daaé, who becomes the obsession of a mysterious, disfigured musical genius" (Wikipedia). Together they discover "[...] the true power of music and love" (Broadway Musical Home). Production: 2008, Capital High School, Charleston, West Virginia. Digital Formats: MP3, audio CD, vinyl, audio cassette, DVD (Royal Albert Hall performance), DVD (movie version).

- South Pacific (prejudice and stereotyping, racism, forbidden love, friendship). "The plot centers on an American nurse stationed on a South Pacific island during World War II who falls in love with a middle-aged expatriate French plantation owner but struggles to accept his mixed-race children. A secondary romance, between a U.S. lieutenant and a young Tonkinese woman, explores his fears of the social consequences should he marry his Asian sweetheart" (Wikipedia).

\section{The Broadway Musical in the Classroom}

Selective Broadway musicals can be used in classroom settings to encourage prosocial behaviors among youth. Among others, teaching venues include health, community, and social life, cultural studies, and historical awareness. Examples of instructional strategies follow. Suggested digital recourses are listed in the Notes section of this discussion

\section{Community, Social Life, and the Person}

Youth can be encouraged to consider what community means and the obligations they have to promote community through prosocial activities. Use this theme to discuss how social and personal conflicts can arise with different understandings of community and the various facets of social life, including freedom of expression.

Discuss how these elements are revealed in Billy Elliot, and how he interacts with family, community, and the social and political life that surrounds him. Several lyrics in Billy Elliot express Billy's need for self-expression in becoming a ballet dancer, and how his family and community come together to support his dream. These lyrics include "Grandma's Song," "The Letter," "He Could Be a Star," and "Express Yourself."

Fiddler on the Roof focuses on community and traditions, and the conflicts they pose for people and the community. Its themes of racism, prejudice, stereotyping, and political oppression are strongly detailed. Lyrics that present these themes include "Tradition, and "Anatevka" (i.e., forced from their village by political oppression 


\section{Racism and Diversity}

Racism and a lack of acceptance of diversity among people are problems in society. Help youth understand these conflicts and the ways prosocial behaviors can help address them in positive ways. South Pacific and Oklahoma! offer teachable examples and show how these issues affect individuals. "You've Got to Be Carefully Taught" reminds us how racism is engrained through social conditioning.

Oklahoma! celebrates diversity and community. Lyrics highlighted in "Oklahoma," ("Living in a Brand New State [...] You're Doing Fine Oklahoma") and "Farmer and the Cowman." ("Farmer and Cowman can be friends

\section{Health and Prosocial Choices}

How youth make choices affect society as a whole. Bad choices can lead to public health issues. Unhealthy choices regarding smoking, alcohol and drug use are just a few examples that call for prosocial choices. Encourage students to make good prosocial choices regarding their health. Music is popular among youth and can be used to illustrate prosocial health choices. Bad choice in listening and playing music can have unhealthy consequences. In music, this is often evidenced through harm to voice and hearing.

Guide students in understanding how musicians and singers, and even the audiences, need to protect themselves from these losses. Some discussion points might include how singers and musicians can guard against and protect themselves from health problems. Rock singers as well as singers of popular music often suffer voice problems such as vocal fold nodules. Tenosynovitis (muscle lining around joints inflammation) can impede the work of various types of instrumentalists. As audience members attending concerts, ask how youth can protect themselves and others from health problems including accidents.

Both Phantom of the Opera and All Shook Up can be used to introduce health issues such as obsessive behaviors and stalking. All Shook Up explores 1950s youth community and love life based on the music of Elvis Presley. Lyrics include "Jail House Rock," "Love Me Tender," and "Heartbreak Hotel." Ask students to listen to some of these lyrics and consider vocal demands and possible voice and musical problems that young, inexperienced singers and instrumentalists might experience.

Phantom of the Opera is set in a $19^{\text {th }}$ century opera house and considers mental illness, stalking, and obsessive behavior. Ask students to identify health issues found here as well as their resolutions.

Jekyll \& Hyde likewise reveals mental illness and its extreme effects. Help students understand not only this, but the need for self-understanding that leads to a prosocial life. Themes in the lyrics that underscore the complexity of this musical include "Take Me as I Am," "Letting Go," "Good 'N' Evil" and "I Need to Know," "The Way Back." 


\section{Cultural Studies}

Into the Woods is based on a combination of well-known western folktales and reveals human foibles, values, and good behaviors. Traditional folktales have been used to emphasize expected prosocial behaviors as well as expose behaviors that are not accepted within a given society. As such, folktales are often used to study cultural values and norms. These include seizing opportunity, loyalty, facing uncertainly, and the consequences of selfishness. Discuss how folklore can influence prosocial behaviors with students. Have students discuss some of the prosocial behaviors they remember from their younger years. Lyrics which help enforce prosocial behaviors include, "I Know Things Now," "Stay with Me," No One is Alone," and "Children Will Listen.".

\section{History and Society}

Evita is based on history and biography, and reveals a need for self-understanding and acceptance. It is a living portrait of a woman who rises to power from obscurity and hardship to become a powerful and beloved political figure, but near the end of her life she reflects back on her life and wonders if she has made good choices. Lyrics that suggest her struggles include "Don't Cry for Me Argentina" and "Lament."

Les Misérables is a musical adaption of the literary classic by Victor Hugo. It is complex in how it explores human society and individuals caught up in the crossfires of history. It also reveals the oppressive state, the result of extreme poverty, social neglect, and how these often lead to revolution and government overthrow. Lead students in discussing the background of the French Revolution, why and how it happened, and events that influenced it. Discuss its impact on democratic movements that eventually produced reform of legal systems towards a more just and hominine approach to poverty and crime. Highlight the roles of prosocial behaviors and transformation of individual lives found in the musical. Significant lyrics include "What Have I Done?" "Do You Hear The People Sing?" and "I Dreamed A Dream."

\section{Conclusions and Recommendations}

Incorporating musicals into the curriculum requires a great deal of planning and an understanding of youth development and interests. Not all musicals are age appropriate. Talents needed to perform these are essential and include acting and voice skills in addition to musical accompaniments.

Schools strive to encourage involvement of students in activities that will encourage prosocial behaviors. Aside from offering students access to performing and enjoying great music, numerous leading roles are available, and they provide opportunities for large numbers of students to become involved. The prosocial messages are clear. Adult theatrical directing skills and all the needs of stage craft and its management are required. These range from lighting, stage 
designs and construction, and backstage assistance. (Musical Theater [for Kids]. http://www.musical-theater-kids.com/popular-school-musicals.html)

Of course, administrative and parental support must be considered. Public support and the problems of censorship can be expected due to the content and social messages of some musicals.

A review of numerous research studies reported by the American Alliance for Theatre \& Education (2014) indicate that drama improves academic performance and performance on standard test scores (SAT). Drama likewise promotes better school attendances and reading comprehension. In addition, their research review indicates that drama supports improved selfesteem. Drama participation helps at-risk youth and students from lower socio-economic environments overcome gaps in achievements when compared with other youth from more advantaged situations.

Research involving musical performances and youth also show numerous benefits to students. These include the following (Akin):

- High school students involved in music have higher grade averages than nonmusic students in the same high school.

- Music performance classes in elementary schools build basic skills required for entrance into high school performance groups. This curriculum helps students develop cognitive skills.

- A California study showed that studying music encourages the development of academic achievement skills (State of California, 1986).

- Learning to play a musical instrument helps students develop faster physically, mentally, emotionally and socially.

- Instrumental practice enhances coordination, concentration, memory, improvement of eyesight, and hearing acuity. Learning to play an instrument progressively refines the development of the brain and the entire neuromuscular system.

- The Lozanov method developed in Bulgaria now used in the U.S. resulted in higher achievement for students in reading and math, as well as in writing and composition. Classroom behavior was greatly improved, allowing for effective improved time on task.

Page $\mid 11$ 
- In Norway, a connection was found between students having musical competence and high motivation to achieve success in school. Students with interest and competence in school music were found to have a positive correlation with cognitive competence scores.

- Achievement in school music builds student self-image, which is a motivation for academic learning among urban American Afro American middle school students.

I would like to close with a quote from director Peter Brook. He says "[...] when we are persuaded to believe in the truth. Then the theatre and life are the same" (Bradley, p.231).

Professor Bradley also reminds us that the musical is one of the most powerful cultural icons of our age (Bradley p.I). As such, it offers a steadfast means in encouraging prosocial behavior in our youth.

\section{Notes}

American Alliance for Theatre \& Education (2014) "The Effects of Theatre Education." Retrieved from http://www.aate.com/?page=effects.

Bradley, I. (2004). You've Got to Have a Dream. The Message of the Musical. Louisville: Westminster John Knox Press.

"Broadway Musical Home Reviews."

Evita, Fiddler on the Roof. Into the Woods, Jekyll \& Hyde, Les Misérables, Oklahoma!, Phantom of the Opera. Retrieved from http://www.broadwaymusicalhome.com/shows.htm.

Broadway Musical Home. "Broadway Musical Home Reviews." .

. Retrieved from http://www.broadwaymusicalhome.com/shows.htm.

Cherry, K. "What Is Prosocial Behavior?" Retrieved from http://psychology.about.com/od/pindex/g/prosocial-behavior.htm, Sept 19. 2015).

Jones, J. B. (2003). Our Musicals: Ourselves: A Social History of the American Musical Theater. Hanover Brandeis University Press, Published by University Press of New 
England.

Kirle, B. (2005).. Unfinished Show Business: Broadway Musicals as Works-in-Process Carbondale, ILL.: Southern Illinois University.

Musical Theater [for Kids]. Retrieved from http://www.musical-theater-kids.com/popularschool_musicals.html).

Wikipedia. Reviews: All Shook Up. Retrieved from https://en.wikipedia.org/wiki/All_Shook_Up_(musical). Billy Elliot Retrieved from https://en.wikipedia. Evita. Retrieved from https://en.wikipedia.org/wiki/Evita_(musical). Les Misérables. Retrieved from https://en.wikipedia.org/wiki/Les_Mis\%C3\%A9rables_(musical). Oklahoma! Retrieved from Shttps://en.wikipedia.org/wiki/Oklahoma!outh Pacific. Retrieve Fromhttps://en.wikipedia.org/wiki/South_Pacific_(musical)

\section{Major Digital Resources}

All Shook Up (Behaviors: love and caring).

Digital Format: Audio CDs, The Original Broadway cast recording was released on May 31, 2005 by BMG Marketing.

Billy Elliot (Behaviors: self expression, transformations, community, family, conflicts, values). Digital Formats: DVD, Blu-ray and VHS, Universal Studios Home Entertainment, 2001.

Evita (Behaviors: society and community, self; truth and social reality).Digital Formats: Multiple Formats, Closed-captioned, Color, Letterboxed, NTSC, Subtitled, Widescreen, Language: English (Dolby Digital 5.1) Subtitles: Spanish; Rated: PG (Parental Guidance Suggested); Run Time: 135 minutes; Hollywood Pictures Home Entertainment, 1998.

Fiddler on the Roof (Behaviors: family, community, traditions. racism, oppression), Digital Formats. DVD video: NTSC color broadcast system.

Into the Woods (Behaviors: opportunity, loyalty, uncertainly, selfishness). 
Digital Formats: [Burbank, Calif.]: Walt Disney, Burbank, California: Buena Vista Home Entertainment, [2015] [2015] @2015.

Jekyll and Hyde (Behaviors: being-oneself; self-awareness). DVD video: NTSC color broadcast system; Chatsworth, CA : Image Entertainment, (C2006.

Les Misérables (Behaviors: helping others, life transformation, justice, and the political state). Numerous Digital Formats: DVD (movie adaption of musical). Consult amazon.com.

Oklahoma! (Behaviors: accepting diversity, community, democracy).

Digital Formats: Oklahoma! Selections from the Theatre Guild Musical Play Original recording reissued, Original recording premastered, DVD London Stage revival).Consult aamazon.com

Phantom of the Opera (Behaviors: acceptance, redemption). Various formats and Productions: The Phantom of the Opera (Original 1986 London Cast) 2001: Streaming MP3 Music; audio CD, vinyl; .audio Cassette; The Phantom of the Opera at the Royal Albert Hall 2 012; DVD; Blu-ray; The Phantom of the Opera (2004 Movie Soundtrack); The Phantom of the Opera at the Royal Albert Hall: In Celebration of 25 Years 2012; Highlights From The Phantom Of The Opera: The Original London Cast Recording (1986 London Cast)1988.Consullt amazon.com.

South Pacific (prejudice and stereotyping, racism, forbidden love, friendship); Digital Formats (selected): DVD (movie versions, 1958, 2002, 2013), DVD, Original 1949 cast Audio CD, Concert version, Carnegie Hall, 2006). Consult amazon.com 